\title{
Potential of Membrane Technology for Treatment and Reuse of Water from Old Mining Lakes
}

(Potensi Teknologi Membran untuk Rawatan dan Penggunaan Semula Air dari Tasik Lombong Lama)

\author{
Teow Yeit HaAn*, Abdul Wahab Mohammad, Syazaman RAmli, Mohd Shaiful Sajab \\ \& NOORINI IZZATI MOHAMAD MAZUKI
}

\begin{abstract}
The El-Nino phenomenon in early 2014 contributed to the lack of water supply in most Southeast Asian countries. Suggestions have since been made to ensure the continuity of water supply, one of which involves membrane technology to treat mine water so that it is compatible for citizens' use. Accordingly, the objective of this research was to study the efficiency of membrane technology in treating mine water. Our elucidation of all the parameters has showed that the best attainable classification is at Class IV. Although it was still regarded as polluted, the treated mine water can be used as water supply reservoir. For the membranes tested such as ultrafiltration $10 \mathrm{kDa}, 5 \mathrm{kDa}$ and reverse osmosis, the percentage of rejection for chemical oxygen demand is 21-72\%, 40-96\% for total suspended solids and 21-72\% for ammonia nitrogen. The $\mathrm{pH}$ also gradually shifted to almost neutral after the filtration.
\end{abstract}

Keywords: Heavy metal; mine water; membrane technology; water quality parameter; water reuse

\section{ABSTRAK}

Fenomenon cuaca El-Nino pada awal 2014 menyumbang kepada kekurangan bekalan air di kebanyakan negara di Asia Tenggara. Objektif kajian ini adalah untuk mengkaji kecekapan teknologi membran untuk rawatan air lombong dengan membandingkan parameter kualiti air sebelum dan selepas penurasan berdasarkan Indeks Kualiti Air (WQI) seterusnya memberi cadangan reka bentuk loji rawatan air yang merawat air lombong dengan menggunakan teknologi membran. Semua parameter yang dikaji menunjukkan bahawa klasifikasi maksimum yang tercapai adalah Kelas IV. Berdasarkan WQI, walaupun semua air lombong dianggap tercemar tetapi ia masih dapat digunakan sebagai sumber air takungan. Nilai WQI yang berada dalam lingkungan 47-65 dikategorikan sebagai Kelas III dan IV. Untuk membran yang diuji seperti penurasan ultra $10 \mathrm{kDa}, 5 \mathrm{kDa}$ dan osmosis songsang, peratusan penolakan untuk permintaan oksigen kimia adalah 21-72\%, 40-96\% untuk jumlah pepejal terampai dan 21-72\% untuk nitrogen ammonia. pH juga beransur-ansur berubah hampir ke neutral selepas proses penurasan dijalankan.

Kata kunci: Air lombong; logam berat; parameter kualiti air; penggunaan semula air; teknologi membran

\section{INTRODUCTION}

The El-Nino phenomenon hit Southeast Asia in early 2014 and persisted for about 18 months, leading to the movement of hot airs and less rainfall. This caused elevation in the temperatures of the surrounding regions, culminating in the receding of water levels in dam systems and, by extension, water rationing in most of the affected countries. Against this background, suggestions have been made to ensure the continuity of water supply, one of which is to channel the water from mines to dams and rivers for the citizens' use. A former mining area is an area where mining used to be performed that has been abandoned for a long time. Although earlier studies have shown that mine water is safe for daily uses, there is evidence that mine water contains heavy metals. Hence, anxiety has arisen among users concerning the safety and quality mine water. A comprehensive study on mine water from different potential former mining areas is therefore warranted for assessing the safety and quality.
There are five major categories of potential pollutants in mine water, namely physical, chemical (organic), chemical (non-organic), biological, and radiological pollutants, as shown in Table 1. In previous studies, Rozkowski and Rozkowski (1994) and Sivakumar et al. (1994) have stated that the acceptable parameters for mine water are as follows: $500-2000 \mathrm{mg} / \mathrm{L}$ for total dissolved solids (TSS), 10-100 mg/L for suspended solids (SS), < $5 \mathrm{mg} / \mathrm{L}$ for biochemical oxygen demand (BOD), 10-100 $\mathrm{mg} / \mathrm{L}$ for chemical oxygen demand (COD), 7-9.5 for $\mathrm{pH}$, $600-10,000 \mu \mathrm{s} / \mathrm{cm}$ for conductivity and 30-600 units for colour.

Membrane technology is a generic term for a number of a number of separation processes that are similar in their involvement of membranes but are otherwise different in their characteristics. Membranes have widely been implemented as a valuable means of filtering and cleaning in the production of processed water from groundwater, surface water or wastewater. Some studies 
TABLE 1. Potential pollutants in mine water and its categories

\begin{tabular}{|c|c|}
\hline Categories & Pollutant \\
\hline Physical & $\begin{array}{l}\text { Suspended solids } \\
\text { Turbidity } \\
\text { Colour } \\
\text { Temperature } \\
\text { Taste and odour }\end{array}$ \\
\hline $\begin{array}{l}\text { Chemical } \\
\text { (Organic) }\end{array}$ & $\begin{array}{l}\text { Coal } \\
\text { Oil and grease } \\
\text { Soap and detergent } \\
\text { Rubber } \\
\text { Colouring and phenolic compound }\end{array}$ \\
\hline $\begin{array}{c}\text { Chemical } \\
\text { (Non-organic) }\end{array}$ & $\begin{array}{l}\text { Heavy metal ( } \mathrm{Cr}, \mathrm{Hg}, \mathrm{Cu}, \mathrm{Cd}, \mathrm{Pb}, \mathrm{Zn}, \mathrm{Ni}, \mathrm{Mn}, \mathrm{Fe}) \\
\text { Acid } \\
\text { Alkali } \\
\text { Cyanide } \\
\text { Saline solution: } \\
\text { - Cations: } \mathrm{Mg}, \mathrm{Ca}, \mathrm{K}, \mathrm{Na}, \mathrm{Fe}, \mathrm{Mn} \\
\text { - Anions: } \mathrm{Cl}^{-}, \mathrm{SO}_{4}^{-}, \mathrm{NO}_{3}^{-}, \mathrm{HCO}_{3}^{-}, \mathrm{PO}_{4}^{-}\end{array}$ \\
\hline Biological & Bacteria, virus and microorganism \\
\hline Radiological & Uranium, tritium \\
\hline
\end{tabular}

have demonstrated that separation processes through membranes could be effective in treating mine water (Kesieme \& Aral 2015; Mullett et al. 2014). As reported by Kesieme and Aral (2015), sulphate and metal separation efficiency was $>99.99 \%$ and the overall water recovery exceeded $80 \%$. On the other hand, rejection above $95 \%$ for all multivalent cations was achieved by NF 270 membrane in Mullet et al. (2014) research work. Georgescu and Andrei (2000) investigated the application of reverse osmosis (RO) membranes for the treatment of mining and metallurgical wastewater in replacing the conventional treatment method, such as ion exchange, precipitation, electrochemical, filtration and floatation as the need of economic and effective removal methods for heavy metals. Wilmonth et al. (1978) determined the effectiveness of RO membranes in treating the acid mine drainage (AMD) at the EPA Crown Field Site, located near Morgantown, West Virginia.

The main objective of this study was to investigate the potential of different membrane modules (UF membrane with the nominal molecular weight cut-off (MWCO) of $10 \mathrm{kDa}$, UF membrane with MWCO of $5 \mathrm{kDa}$, and RO membrane) used in treating mine water collected from three places in Selangor, Malaysia: Bandar Saujana Putra, Jenjarom (Sample 1), from Taman Putra Perdana, Puchong (Sample 2) and Persiaran Puchong Perdana, Puchong (Sample 3).

\section{EXPERIMENTAL DETAILS}

\section{MATERIALS}

The samples of mine water in this study were collected from three places in Selangor, Malaysia: Bandar Saujana Putra, Jenjarom (Sample 1) with GPS coordinate of $2.9390562000^{\circ}, 101.5844967000^{\circ}$; Taman Putra Perdana, Puchong (Sample 2) with GPS coordinate of $2.942668^{\circ}$, 101.620389 ${ }^{\circ}$; and Persiaran Puchong Perdana, Puchong (Sample 3) with GPS coordinate of $2.998139^{\circ}, 101.636252^{\circ}$. Three different types of flat sheet commercial membranes were purchased from Amfor Inc., Beijing, China. As reported by the manufacturer, UF membranes were made from polyethersulphone (PES) with the nominal MWCOS of $10 \mathrm{kDa}$ and $5 \mathrm{kDa}$; while $\mathrm{pH}$ resistance ranged from 1 to 13 . For the RO membrane, it was made from polyamide thin film composite with $95 \% \mathrm{MgSO}_{4}$ and $99.4 \% \mathrm{NaCl}$ rejection.

\section{MEMBRANE PERFORMANCE EVALUATION}

Membrane Permeability Test Membrane permeability is the simplest method to measure the ability of a membrane to allow fluids to pass through it. A laboratory bench-scale dead-end test unit was used to study the performance of each membrane module (UF membrane with the nominal MWCO of $10 \mathrm{kDa}$, UF membrane with MWCO of $5 \mathrm{kDa}$ and RO membrane).

At the earliest stage of the experiment, ultra-pure water was used as the background solution. The membranes were flushed with ultra-pure water before any process solutions were passed through them. Each membrane module was tested with ultra-pure water to investigate the pure water flux (PWF) at various applied pressures $(P)$. All of the membranes were cut into a disc shape with an effective membrane filtration area of $46.2 \mathrm{~cm}^{2}$ (including the area covered by the O-ring). Continuous stirring was provided throughout the membrane filtration process to reduce the concentration polarization effect on the membrane surface. The specific pressure-driven PWF of each membrane module at a constant pressure can be described by Darcy's law: 


$$
J_{W F}=\frac{1}{A} \frac{d V}{d t}=\frac{\Delta P}{\eta\left(R_{m}+R_{c}\right)}
$$

where $J$ is the specific membrane water flux $\left(\mathrm{L} / \mathrm{m}^{2} \mathrm{~h}\right) ; A$ is the membrane effective area $\left(\mathrm{m}^{2}\right) ; V$ is the volume of permeating water $(\mathrm{L})$ and; $t$ is the filtration time required to collect $V(\mathrm{~h}), \Delta P$ represents the transmembrane pressure (TMP); $\eta$ is the dynamic viscosity of the water; $R_{m}$ is the membrane resistance to the pure water flux; and $R_{c}$ stands for the deposited resistance.

\section{MEMBRANE TREATMENT ON MINE WATER}

The effectiveness of the membranes in treating mine water was measured by the degree to which the feed material was retained during operation. It was determined under 5 bar using the raw mine water samples collected from the different sampling locations as aforementioned in previous section. In order to alleviate the impact of compaction, the pre-filtration study with pure water was first conducted at 5 bar for 30 min until a steady-state flux was achieved. The quality of the treated mine water was analyzed in terms of BOD, COD, DO, $\mathrm{NH}_{3}-\mathrm{N}$, SS and $\mathrm{pH}$ for subsequent classification based on the Water Quality Index (WQI) calculation as follows:

$$
\begin{aligned}
\mathrm{WQI}= & 0.22 \times \text { SIDO }+0.19 \text { SIBOD }+0.16 \text { SICOD } \\
& +0.15 \text { SIAN }+0.16 \text { SISS }+0.12 \text { SIpH }
\end{aligned}
$$

Based on the Malaysia WQI, the water quality is classified according to one of the following categories shown in Table 2 (Department of Environment Malaysia (DOE) 2008).

\section{ANALYTICAL METHODS}

Inductively Coupled Plasma Electron Spectrometry (ICPES) ICPES was used to detect the presence of metals listed in periodic table at concentrations as low as one part in $10^{15}$ (part per quadrillion, ppq).

pH Analysis The solubility of metals in water is mainly dependent on the $\mathrm{pH}$ of the water sample. Low $\mathrm{pH}$ values (acidic conditions) contribute to higher metal solubility whereas high $\mathrm{pH}$ values (alkaline conditions) lead to the precipitation of metal oxides. The $\mathrm{pH}$ of the water samples was measured using a pH meter (Eutech Instruments Pte Ltd., Singapore).

Dissolved Oxygen (DO) Analysis DO refers to the level of free, non-compound oxygen present in water or other liquids. It is measured in the number of milligrams of oxygen dissolved in a liter of water $(\mathrm{mg} / \mathrm{L})$ using a DO meter (Thermo Fisher Scientific, Inc., U.S).

Ammonia Nitrogen $\left(\mathrm{NH}_{3}-\mathrm{N}\right)$ Analysis $\mathrm{NH}_{3}-\mathrm{N}$ was analyzed using the Nessler method for quantifying the amount of ammonia, a toxic pollutant often found in liquid organic waste products. The apparatus used in the $\mathrm{NH}_{3}-\mathrm{N}$ study was DR 3900 Benchtop Spectrophotometer with RFID* Technology (Hach Company, Colorado, USA) at the wavelength of $425 \mathrm{~nm}$.

Chemical Oxygen Demand (COD) Analysis COD test serves to quantify the capacity of water to consume oxygen during the decomposition of organic matters and the oxidation of inorganic chemicals such as ammonia and nitrite; it is therefore commonly used to indirectly measure the amounts of organic compounds in water. The COD was measured using the reactor digestion method by means of a DR 3900 Benchtop Spectrophotometer with RFID* Technology (Hach Company, Colorado, USA). Two types of vials, COD Digestion Reagent of low range (LR) 3-150 mg/L (Hach Company, Colorado, USA) and COD Digestion Reagent of high range (HR) 20-1500 mg/L (Hach Company, Colorado, USA), were applied for low-range and high-range levels of contamination, respectively.

Biochemical Oxygen Demand (BOD) Analysis BOD is the amount of dissolved oxygen needed by aerobic biological organisms in a body of water to break down organic materials present in a given water sample at certain temperature over a specific time period. The 5-day BOD was measured by the dilution method, a standard method recognized by the U.S. Environmental Protection Agency (EPA) for the examination of water and wastewater.

Total Suspended Solids (TSS) Analysis TSS are solids in water that can be trapped by a filter. They include a wide variety of materials, such as silt, decaying plant and animal matters, industrial wastes and sewage. The TSSs of the

TABLE 2. Malaysian Quality Index (Department of Environment Malaysia (DOE) 2008)

\begin{tabular}{cccccc}
\hline \multirow{2}{*}{ Parameter } & \multicolumn{5}{c}{ Class } \\
\cline { 2 - 6 } & $\mathrm{I}$ & $\mathrm{II}$ & $\mathrm{III}$ & $\mathrm{IV}$ & $\mathrm{V}$ \\
\hline $\mathrm{NH}_{3}-\mathrm{N}$ & $<0.1$ & $0.1-0.3$ & $0.3-0.9$ & $0.9-2.7$ & $>2.7$ \\
$\mathrm{BOD}$ & $<1$ & $1-3$ & $3-6$ & $6-12$ & $>12$ \\
$\mathrm{COD}$ & $<10$ & $10-25$ & $25-50$ & $50-100$ & $>100$ \\
$\mathrm{DO}$ & $>7$ & $5-7$ & $3-5$ & $1-3$ & $<1$ \\
pH & $>7$ & $6-7$ & $5-6$ & $<5$ & $<5$ \\
TSS & $<2.5$ & $25-50$ & $50-150$ & $30-50$ & $>300$ \\
WQI & $>92.7$ & $76.5-92.7$ & $51.9-76.5$ & $31-51.9$ & $<31.0$ \\
\hline
\end{tabular}


sample was directly measured by the DR 3900 Benchtop Spectrophotometer with RFID* Technology, using the photometric method which did not require the filtration or ignition/weighing at the wavelength of $810 \mathrm{~nm}$.

\section{RESULTS AND DISCUSSION}

\section{ULTRA PURE WATER FLUX ANALYSIS}

In this study, the PWF of each membrane module with different morphologies was measured by using (1). The PWFs for the UF membrane (10 kDa), UF membrane (5 $\mathrm{kDa})$ and RO membrane are illustrated in Figures 1(a), 1(b) and 1(c), respectively. It is evident that the permeate flux of water for all types of membrane modules increased proportionally with the operating pressure from the feed side. This indicates permeation of the membranes is a pressure-driven filtration (GEA Filtration 2010).

However, the PWF of the membranes varied as a function of the operating pressure for the three different membrane modules. Comparison shows that the UF membrane $(10 \mathrm{kDa})$ with the largest pore size exhibited the highest PWF, $59.744 \mathrm{~L} / \mathrm{m}^{2} \mathrm{~h}$, followed by that of the UF membrane (10 kDa), $46.153 \mathrm{~L} / \mathrm{m}^{2} \mathrm{~h}$; while the RO

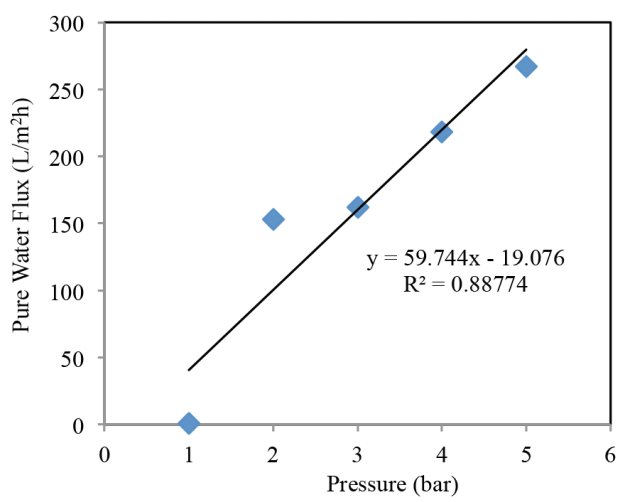

(a) membrane exhibited the lowest PWF, $5.748 \mathrm{~L} / \mathrm{m}^{2} \mathrm{~h}$, due to its tight membrane structure. The slight deviations from linearity at higher feed pressures could be due to compaction of the membranes.

Furthermore, (1) shows that the PWF is inversely proportional to membrane resistance, $R_{m}$. With increasing $R_{m}$, most of the water molecules will be retained on the feed side of the membrane, causing lesser water permeation. An increase in the $R_{m}$ may be due to a decrease in the membrane pore size, which will be further investigated in the following section through the measurement of solute rejection of different water samples.

\section{MEMBRANE TREATMENT ON MINE WATER}

In order to evaluate the efficiency of the membrane modules on mine water treatment, the permeate flux and percentage rejection $(\% R)$ of each membrane module were measured. Figure 2(a), 2(b) and 2(c) shows the PWF and permeate water flux of each membrane module in filtering the mine water Samples 1, 2 and 3, respectively. Comparing the PWF and permeate water flux for each membrane module for a specific mine water sample, the flux associated with the filtering of ultra-pure water was found to be higher than the permeate water flux associated

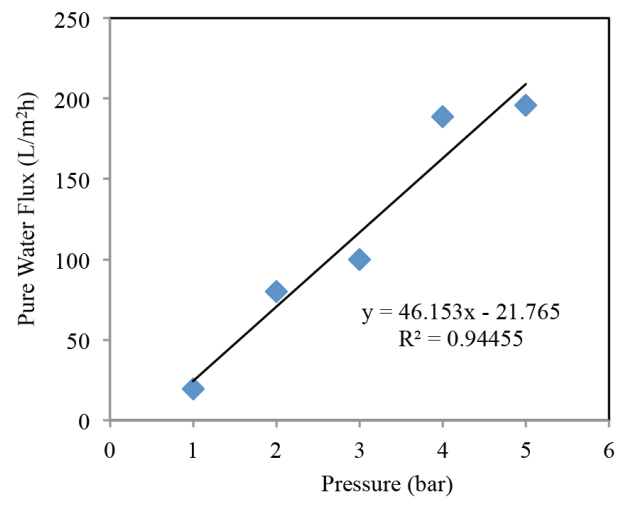

(b)

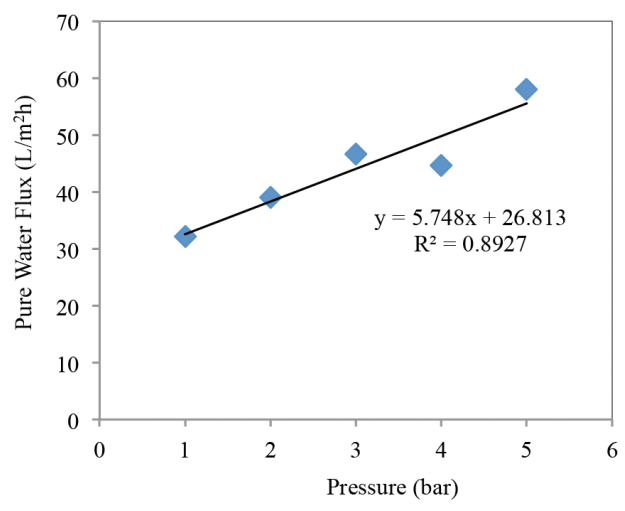

(c)

FIGURE 1. Pure water flux (PWF) of membrane as a function of applied pressure (a) UF $10 \mathrm{kDa}$ Membrane (b) UF 5kDa Membrane (c) RO Membrane 


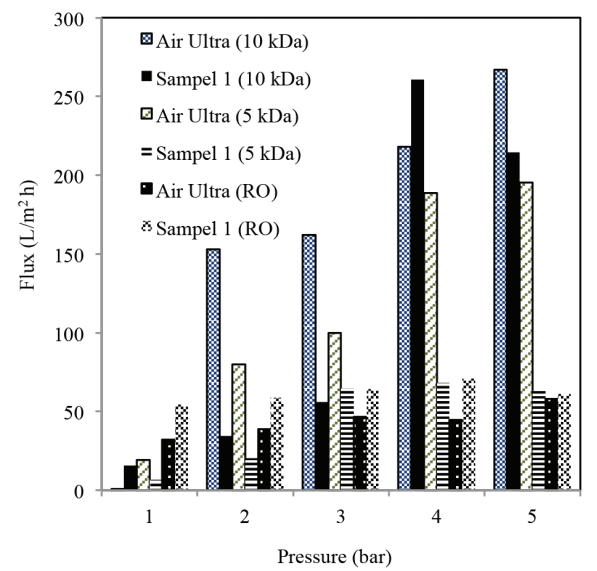

(a)

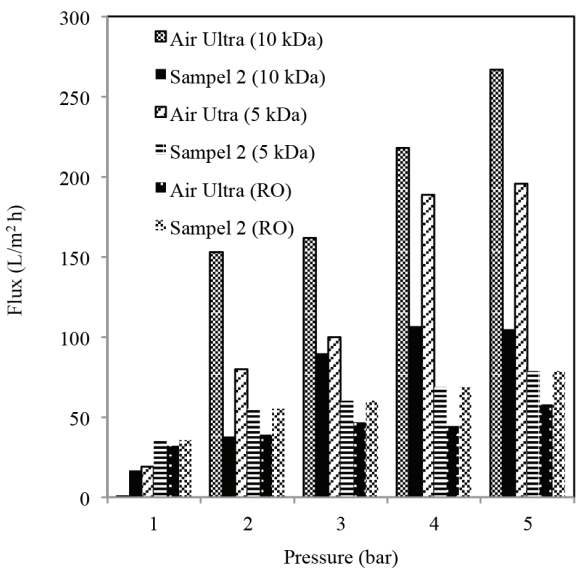

(b)

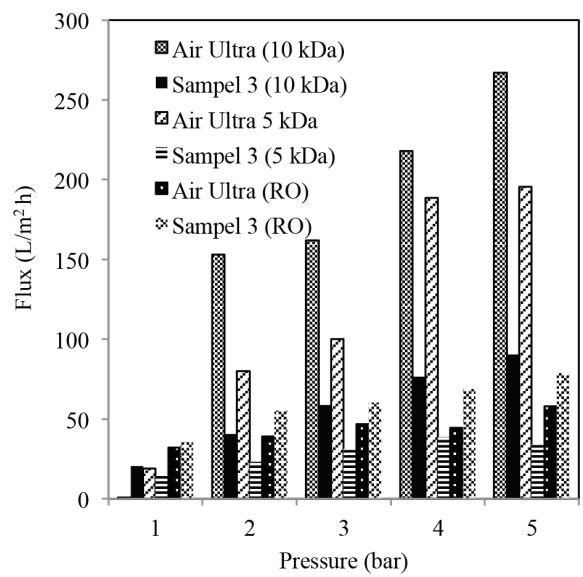

(c)

FIGURE 2. Pure water flux (PWF) and permeate water flux in filtering mine water sample at different applied pressure (a) Sample 1 (b) Sample 2 (c) Sample 3

with the filtering of the mine water sample. This is because the filtration of mine water through the membranes might have led to the formation of a deposit on the membrane outer surface which blocked the open pores, resulting in a decline in the flux (Field 2010). This membrane fouling phenomenon is mainly due to the combined effects of Donnan exclusion and the sieving mechanism during the filtration (Nanda et al. 2010). Besides, the immersion of the membranes in water for long periods of time during the filtration might have led to the formation of a gel layer on the membrane surface that further contributed to the fouling effect on the membrane. Compared to raw mine water which may result in membrane fouling, ultra-pure water does not contain any foreign substances.

Although a diminished flux was observed for all membrane modules in the treatment of mine water, the RO membrane was found to have the least decline. This phenomenon was attributed to the extremely small average pore size of the RO membrane, which led to less formation of pore blocking attributed by large solute particles into the membrane matrix. Additionally, solute particles deposited on membrane surfaces were easily flushed away by the water flux on the feed side. Only certain segments on the membrane surface was fouled (pore blockage) by a small fraction of solute particles with a smaller size. Furthermore, the incomplete compaction of the RO membrane might be another factor that contributed to the higher permeate water flux in filtering the mine water sample than PWF, as the membrane pores were not fully open at the early stage of the filtration (Hydranautics 2001).

Generally, the membrane acts as a primary filtering medium before a fouling layer is formed on its surface; upon its formation, however, such a fouling layer itself becomes the primary filtering medium, resulting in significant decrease in water permeation.

\section{PERMEATE WATER QUALITY AFTER MEMBRANE FILTRATION PROCESS}

The permeate water quality of Samples 1, 2 and 3 after filtration by the different membranes were characterized, for which the results are tabulated in Tables 3, 4 and 5, respectively. The parameters used in analyzing the water samples were $\mathrm{pH}$, color, turbidity, conductivity, total 
TABLE 3. Sample 1 permeate water under different membrane filtration processes

\begin{tabular}{|c|c|c|c|c|c|}
\hline \multirow{2}{*}{ Parameters } & \multirow{2}{*}{ Unit } & \multicolumn{4}{|c|}{ Sample 1 (Bandar Saujana Putra) } \\
\hline & & Raw & $10 \mathrm{kDa}$ & $5 \mathrm{kDa}$ & $\mathrm{RO}$ \\
\hline $\mathrm{pH}$ & - & 3.80 & 3.80 & 4.20 & 4.40 \\
\hline Colour & $\mathrm{mg} / \mathrm{L}$ & 9 & 3 & - & - \\
\hline Turbidity & NTU & 1.100 & 0.182 & - & - \\
\hline Conductivity & $\mu \mathrm{S} / \mathrm{cm}$ & 215.0 & 196.2 & 195.9 & 154.4 \\
\hline Total dissolved solids (TDS) & $\mathrm{mg} / \mathrm{L}$ & 105.4 & 99.0 & 97.5 & 77.3 \\
\hline Ammonia nitrogen $\left(\mathrm{NH}_{3}-\mathrm{N}\right)$ & $\mathrm{mg} / \mathrm{L}$ & 0.70 & 0.55 & 0.52 & 0.15 \\
\hline Suspended solids (SS) & $\mathrm{mg}$ & 0.0005 & 0.0003 & 0.0004 & 0.0002 \\
\hline Total suspended solids (TSS) & $\mathrm{mg} / \mathrm{L}$ & 0.005 & 0.003 & 0.004 & 0.002 \\
\hline Chemical oxygen demand (COD) & $\mathrm{mg} / \mathrm{L}$ & 26.9 & 21.5 & 9.4 & 6.0 \\
\hline Biochemical oxygen demand (BOD) & $\mathrm{mg} / \mathrm{L}$ & 8.9 & 10.7 & 33.5 & 17.5 \\
\hline Dissolved oxygen (DO) & $\mathrm{mg} / \mathrm{L}$ & 5.03 & 4.52 & 2.19 & 5.61 \\
\hline
\end{tabular}

TABLE 4. Sample 2 permeate water under different membrane filtration processes

\begin{tabular}{|c|c|c|c|c|c|}
\hline \multirow{2}{*}{ Parameters } & \multirow{2}{*}{ Unit } & \multicolumn{4}{|c|}{ Sample 2 (Bandar Putra Perdana) } \\
\hline & & Raw & $\mathrm{UF} 10 \mathrm{kDa}$ & UF $5 \mathrm{kDa}$ & RO \\
\hline $\mathrm{pH}$ & - & 6.80 & 7.47 & 6.60 & 7.20 \\
\hline Colour & $\mathrm{mg} / \mathrm{L}$ & 13 & - & - & - \\
\hline Turbidity & NTU & 2.900 & 0.312 & - & - \\
\hline Conductivity & $\mu \mathrm{S} / \mathrm{cm}$ & 222.0 & 208.5 & 176.3 & 144.3 \\
\hline Total dissolved solids (TDS) & $\mathrm{mg} / \mathrm{L}$ & 110.3 & 107.8 & 104.0 & 71.0 \\
\hline Ammonia nitrogen $\left(\mathrm{NH}_{3}-\mathrm{N}\right)$ & $\mathrm{mg} / \mathrm{L}$ & 0.76 & 0.46 & 0.43 & 0.36 \\
\hline Suspended solids (SS) & $\mathrm{mg}$ & 0.0031 & 0.0010 & 0.0006 & 0.0006 \\
\hline Total suspended solids (TSS) & $\mathrm{mg} / \mathrm{L}$ & 0.031 & 0.010 & 0.006 & 0.006 \\
\hline Chemical oxygen demand (COD) & $\mathrm{mg} / \mathrm{L}$ & 27.3 & 21.7 & 15.3 & 15.0 \\
\hline Biochemical oxygen demand (BOD) & $\mathrm{mg} / \mathrm{L}$ & 11.2 & 45.0 & 17.1 & 20.4 \\
\hline Dissolved oxygen (DO) & $\mathrm{mg} / \mathrm{L}$ & 4.98 & 4.96 & 2.45 & 4.88 \\
\hline
\end{tabular}

TABLE 5. Sample 3 permeate water under different membrane filtration processes

\begin{tabular}{|c|c|c|c|c|c|}
\hline \multirow{2}{*}{ Parameters } & \multirow{2}{*}{ Unit } & \multicolumn{4}{|c|}{ Sample 3 (Bandar Puchong Perdana) } \\
\hline & & Raw & $\mathrm{UF} 10 \mathrm{kDa}$ & UF $5 \mathrm{kDa}$ & RO \\
\hline $\mathrm{pH}$ & - & 7.70 & 7.66 & 7.20 & 7.30 \\
\hline Colour & $\mathrm{mg} / \mathrm{L}$ & 2 & - & - & - \\
\hline Turbidity & NTU & 5.720 & 0.202 & - & - \\
\hline Conductivity & $\mu \mathrm{S} / \mathrm{cm}$ & 224.0 & 221.1 & 213.4 & 138.6 \\
\hline Total dissolved solids (TDS) & $\mathrm{mg} / \mathrm{L}$ & 111.7 & 109.0 & 106.2 & 67.4 \\
\hline Ammonia nitrogen $\left(\mathrm{NH}_{3}-\mathrm{N}\right)$ & $\mathrm{mg} / \mathrm{L}$ & 0.31 & 0.28 & 0.27 & 0.19 \\
\hline Suspended solids (SS) & $\mathrm{mg}$ & 0.0028 & 0.0010 & 0.0006 & 0.0001 \\
\hline Total suspended solids (TSS) & $\mathrm{mg} / \mathrm{L}$ & 0.028 & 0.010 & 0.006 & 0.001 \\
\hline Chemical oxygen demand (COD) & $\mathrm{mg} / \mathrm{L}$ & 18.1 & 16.2 & 8.4 & 3.9 \\
\hline Biochemical oxygen demand (BOD) & $\mathrm{mg} / \mathrm{L}$ & 11.3 & 11.2 & 10.1 & 11.7 \\
\hline Dissolved oxygen (DO) & $\mathrm{mg} / \mathrm{L}$ & 5.35 & 4.98 & 2.53 & 5.52 \\
\hline
\end{tabular}

dissolved solids (TDS), $\mathrm{NH}_{3}-\mathrm{N}$, SS, TSS, COD, BOD and DO. On the other hand, the heavy metal contents of Samples 1, 2 , and 3 after filtration by the different membranes were also characterized, for which the results are tabulated in Tables 6, 7 and 8, respectively.

Visualization of the mine water samples showed that Sample 3 exhibited the least color followed by Sample 2 , and lastly by Sample 1, whereas the examination of turbidity showed (in the opposite order) that Sample 1 exhibited the least turbidity, followed by Sample 2 and lastly by Sample 3 .

Membrane treatment on the mine water samples had successfully reduced the color and turbidity of the samples, especially for Samples 2 and 3 which produced almost crystal clear permeate water, despite the membrane modules that was used in the filtration. By contrast, for the filtration of Sample 1, the UF membrane $(5 \mathrm{kDa})$ and RO membrane modules yielded similar permeate 
TABLE 6. Heavy metals content of Sample 1 permeate water under different membrane filtration processes

\begin{tabular}{|c|c|c|c|c|c|}
\hline \multirow{2}{*}{ Heavy Metals } & \multirow{2}{*}{ Unit } & \multicolumn{4}{|c|}{ Sample 1 (Bandar Saujana Putra) } \\
\hline & & Raw & UF $10 \mathrm{kDa}$ & UF $5 \mathrm{kDa}$ & $\mathrm{RO}$ \\
\hline Chromium $(\mathrm{Cr})$ & $\times 10^{4} \mathrm{mg} / \mathrm{L}$ & 116.7 & 101.6 & 72.9 & 5.7 \\
\hline Copper $(\mathrm{Cu})$ & $\times 10^{4} \mathrm{mg} / \mathrm{L}$ & 917.7 & 396.1 & 381.2 & 59.6 \\
\hline Cadmium (Cd) & $\times 10^{4} \mathrm{mg} / \mathrm{L}$ & 12.6 & 10.5 & 8.5 & 8.1 \\
\hline Lead $(\mathrm{Pb})$ & $\times 10^{4} \mathrm{mg} / \mathrm{L}$ & 152.7 & 145.0 & 81.4 & 72.8 \\
\hline $\operatorname{Zinc}(\mathrm{Zn})$ & $\times 10^{4} \mathrm{mg} / \mathrm{L}$ & 3047.6 & 2111.9 & 1974.4 & 1387.7 \\
\hline Nickel (Ni) & $\times 10^{4} \mathrm{mg} / \mathrm{L}$ & 528.0 & 443.5 & 403.1 & 290.0 \\
\hline Sodium (Na) & $\times 10^{4} \mathrm{mg} / \mathrm{L}$ & 27584.5 & 26510.0 & 26002.5 & 22494.9 \\
\hline Silver (Ag) & $\times 10^{4} \mathrm{mg} / \mathrm{L}$ & 915.8 & 465.7 & 364.5 & 78.3 \\
\hline Selenium (Se) & $\times 10^{4} \mathrm{mg} / \mathrm{L}$ & 5.3 & 5.1 & 5.1 & 2.5 \\
\hline Barium (Ba) & $\times 10^{4} \mathrm{mg} / \mathrm{L}$ & 359.2 & 345.0 & 344.9 & 301.2 \\
\hline Boron (B) & $\times 10^{4} \mathrm{mg} / \mathrm{L}$ & 187.9 & 177.5 & 176.1 & 159.0 \\
\hline
\end{tabular}

TABLE 7. Heavy metals content of Sample 2 permeate water under different membrane filtration processes

\begin{tabular}{|c|c|c|c|c|c|}
\hline \multirow{2}{*}{ Heavy metals } & \multirow{2}{*}{ Unit } & \multicolumn{4}{|c|}{ Sample 2 (Bandar Putra Perdana) } \\
\hline & & Raw & UF $10 \mathrm{kDa}$ & UF $5 \mathrm{kDa}$ & RO \\
\hline Chromium (Cr) & $\times 10^{4} \mathrm{mg} / \mathrm{L}$ & 48.5 & 46.7 & 44.9 & 44.1 \\
\hline Copper $(\mathrm{Cu})$ & $\times 10^{4} \mathrm{mg} / \mathrm{L}$ & 82.9 & 80.6 & 78.8 & 13.9 \\
\hline Cadmium (Cd) & $\times 10^{4} \mathrm{mg} / \mathrm{L}$ & 1.4 & 0.5 & 0.5 & 0.4 \\
\hline Lead $(\mathrm{Pb})$ & $\times 10^{4} \mathrm{mg} / \mathrm{L}$ & 1.1 & 0.6 & 0.1 & 0.0 \\
\hline Zinc (Zn) & $\times 10^{4} \mathrm{mg} / \mathrm{L}$ & 41.5 & 41.4 & 25.0 & 20.1 \\
\hline Nickel (Ni) & $\times 10^{4} \mathrm{mg} / \mathrm{L}$ & 33.6 & 26.3 & 19.7 & 8.8 \\
\hline Sodium $(\mathrm{Na})$ & $\times 10^{4} \mathrm{mg} / \mathrm{L}$ & 41117.1 & 39557.9 & 39067.8 & 38656.7 \\
\hline Silver (Ag) & $\times 10^{4} \mathrm{mg} / \mathrm{L}$ & 162.2 & 31.7 & 21.8 & 11.0 \\
\hline Selenium $(\mathrm{Se})$ & $\times 10^{4} \mathrm{mg} / \mathrm{L}$ & 3.2 & 2.4 & 2.1 & 0.9 \\
\hline Barium (Ba) & $\times 10^{4} \mathrm{mg} / \mathrm{L}$ & 51.5 & 51.2 & 50.8 & 45.2 \\
\hline Boron (B) & $\times 10^{4} \mathrm{mg} / \mathrm{L}$ & 293.4 & 283.0 & 280.8 & 277.7 \\
\hline
\end{tabular}

TABLE 8 . Heavy metals content of Sample 3 permeate water under different membrane filtration processes

\begin{tabular}{|c|c|c|c|c|c|}
\hline \multirow{2}{*}{ Heavy Metals } & \multirow{2}{*}{ Unit } & \multicolumn{4}{|c|}{ Sample 3 (Bandar Puchong Perdana) } \\
\hline & & Raw & UF $10 \mathrm{kDa}$ & UF $5 \mathrm{kDa}$ & $\mathrm{RO}$ \\
\hline Chromium $(\mathrm{Cr})$ & $\times 10^{4} \mathrm{mg} / \mathrm{L}$ & 56.7 & 55.2 & 48.5 & 39.4 \\
\hline Copper $(\mathrm{Cu})$ & $\times 10^{4} \mathrm{mg} / \mathrm{L}$ & 73.9 & 59.9 & 57.6 & 6.0 \\
\hline Cadmium (Cd) & $\times 10^{4} \mathrm{mg} / \mathrm{L}$ & 0.8 & 0.4 & 0.4 & 0.4 \\
\hline Lead $(\mathrm{Pb})$ & $\times 10^{4} \mathrm{mg} / \mathrm{L}$ & 3.0 & 2.9 & 0.2 & 0.0 \\
\hline Zinc $(\mathrm{Zn})$ & $\times 10^{4} \mathrm{mg} / \mathrm{L}$ & 35.5 & 35.0 & 34.7 & 7.6 \\
\hline Nickel (Ni) & $\times 10^{4} \mathrm{mg} / \mathrm{L}$ & 57.8 & 46.5 & 22.8 & 14.6 \\
\hline Sodium (Na) & $\times 10^{4} \mathrm{mg} / \mathrm{L}$ & 72679.3 & 71601.9 & 71369.5 & 71078.4 \\
\hline Silver (Ag) & $\times 10^{4} \mathrm{mg} / \mathrm{L}$ & 84.5 & 59.1 & 49.8 & 19.1 \\
\hline Selenium (Se) & $\times 10^{4} \mathrm{mg} / \mathrm{L}$ & 6.5 & 6.1 & 5.9 & 3.0 \\
\hline Barium (Ba) & $\times 10^{4} \mathrm{mg} / \mathrm{L}$ & 135.2 & 114.6 & 112.4 & 91.2 \\
\hline Boron (B) & $\times 10^{4} \mathrm{mg} / \mathrm{L}$ & 380.7 & 360.1 & 353.7 & 334.7 \\
\hline
\end{tabular}

water qualities; for the UF membrane $(10 \mathrm{kDa})$, its high permeability attributed to the larger pore size as was offset by the diminished rejection capability.

\section{AMMONIA NITROGEN $\left(\mathrm{NH}_{3}-\mathrm{N}\right)$}

The $\mathrm{NH}_{3}-\mathrm{N}$ contents in all three raw mine water samples were found to be minimal: $0.70,0.76$, and $0.31 \mathrm{mg} / \mathrm{L}$ for Samples 1, 2 and 3, respectively. Based on such a
$\mathrm{NH}_{3}-\mathrm{N}$ concentration range the samples are accordingly categorized as Class III water, indicating that the water is suitable for recreational purposes but further treatment is warranted before being supplied to residential areas.

The UF membrane (10 kDa), UF membrane ( $5 \mathrm{kDa})$ and RO membrane modules were applied in the further treatment of these raw mine water samples. All the used membrane modules were found to reduce the $\mathrm{NH}_{3}-\mathrm{N}$ content in the water samples. The extent of $\mathrm{NH}_{3}-\mathrm{N}$ 
reduction was dependent on the rejection capability of the membrane which was predominantly governed by the membrane morphology. In this regard, the RO membrane module with its underlying tight membrane structure greatly reduced the $\mathrm{NH}_{3}-\mathrm{N}$ content of the raw mine water samples. The $\mathrm{NH}_{3}-\mathrm{N}$ contents of the raw mine water samples were reduced to $0.15,0.36$ and $0.19 \mathrm{mg} / \mathrm{L}$ for Samples 1, 2 and 3, respectively. The reduction of the $\mathrm{NH}_{3}-\mathrm{N}$ content had eventually enabled the re-classification of the resultant permeate water as Class II water, indicating the suitability for water supply and fishery (Jabatan Alam Sekitar 2010).

\section{BIOCHEMICAL OXYGEN DEMAND (BOD)}

The BOD readings for the raw mine water samples 1,2 and 3 are 8.9,11.2 and $11.3 \mathrm{mg} / \mathrm{L}$, respectively. Previous studies by Rozkowski and Rozkowski (1994) and Sivakumar et al. (1994) demonstrated that the BOD value of their collected mine water was lower, which was only $5 \mathrm{mg} / \mathrm{L}$. The higher BOD value of the local raw mine water is mainly attributed to the growth of plants and the decay of biologically active organic matters, both of which might be unnaturally accelerated when nutrients and sunlight are overly abundant in Malaysia. The population of aquatic microorganisms would therefore tend to increase in proportion to the amount of organic compounds available. Under such circumstances, more dissolved oxygen would be needed by these proliferating aquatic microorganisms to degrade the organic compounds, releasing energy necessary for growth and reproduction.

Based on resultant BOD readings in this study, the mine water samples are categorized as Class IV water, indicating that the water is suitable for supply but further treatment is warranted. However, an unanticipated increase has been observed in the BOD value of the permeate water yielded from the membrane filtration. This might be due to the blooming population of the aquatic microorganisms in the interval, as the experiment for this study had not carried out in the same period of time (Brake Perry 1998).

\section{CHEMICAL OXYGEN DEMAND (COD)}

The COD readings for the raw mine water samples 1,2 and 3 are 26.9, 27.3 and $18.1 \mathrm{mg} / \mathrm{L}$, respectively, which are in range with the findings by Rozkowski and Rozkowski (1994) and Sivakumar et al. (1994) ranging from 10 to 100 $\mathrm{mg} / \mathrm{L}$. Similar to the $\mathrm{NH}_{3}-\mathrm{N}$ analysis, based on the resultant COD readings in this study, the raw mine water samples are categorized as Class II and Class III water, indicating that the water is suitable to be used for recreational purposes but further treatment is warranted before it is supplied to residential areas.

The application of different membrane modules managed to reduce the COD of the raw mine water to different extents: $10-20 \%$ for the UF membrane (10 kDa), $43-65 \%$ for the UF membrane $(5 \mathrm{kDa})$ and $45-78 \%$ for the RO membrane. The RO membrane module, considering its smallest average pore size among all membrane modules used in this study, demonstrated the highest rejection of COD for all different raw mine water samples. With its smaller membrane pore size, the RO membrane module could achieve excellent separation as most of the solute would be retained on the feed side of the membrane, causing a higher rejection percentage $(R \%)$ with better permeate water quality suitable for residential use.

\section{DISSOLVED OXYGEN (DO)}

Oxygen in water body is measured in its dissolved form as DO, a parameter that is directly related to the BOD value obtained, since a higher BOD value means more amount of oxygen has been consumed by aquatic microorganisms in breaking down organic matters, thus, the DO levels will decline. The DO readings for the raw mine water Samples 1, 2 and 3 are $5.03,4.98$ and $5.35 \mathrm{mg} / \mathrm{L}$, respectively, based on which the samples are categorized as Class III. In common practice, the DO values of the samples were expected to increase after the membrane treatment. However, due to the long storage period of the raw mine water sample, the blooming of the aquatic microorganisms had consumed more oxygen in degrading the organic substances in the water samples thus further reducing the DO value to 2-5 $\mathrm{mg} / \mathrm{L}$ (Baird et al. 2012).

\section{$\mathrm{pH}$}

The $\mathrm{pH}$ values for Sample 1, 2 and 3 are 3.8, 6.8 and 7.7 , respectively. Sample 1 with a $\mathrm{pH}$ less than 7 is acidic and has been classified as Class IV water due to its high concentration of heavy metals such as silver and copper (Bernal \& McGrath 1994). For Sample 1, the concentrations of silver and copper are 0.0915 and 0.9177 $\mathrm{mg} / \mathrm{L}$, respectively; this contrasts markedly with the findings for Sample $2(0.01622$ and $0.00829 \mathrm{mg} / \mathrm{L})$ and for Sample $3(0.00845$ and $0.00739 \mathrm{mg} / \mathrm{L})$. Accordingly, with the lower contents of heavy metal in the water sample, the $\mathrm{pH}$ values of Samples 2 and $3 \mathrm{pH}$ were close to neutrality, based on which the two samples are categorized as Class I and Class II water. After the membrane filtration, the $\mathrm{pH}$ value of Sample 1 was elevated, reflecting the reduction of the heavy metals.

\section{TOTAL SUSPENDED SOLIDS (TSS)}

The TSS was used as an indicator to determine inorganic materials larger than 2 microns in the water column in this study. It is a critical parameter for determining water clarity: the more the solids present in the water, the less clear the water will be. The TSS readings for raw mine water Samples 1, 2 and 3 are 0.005, 0.031 and 0.028 $\mathrm{mg} / \mathrm{L}$, respectively, which could include materials drifting or floating in the water, from sediment, silt and sand to plankton and algae. The membrane filtration in this study had significantly reduced the TSS value of the water sample, especially the RO membrane module that reduced it to 
almost zero. Suspended solids with a particle diameter larger than the membrane pore size would often be retained on the feed side, through which only water molecules were allowed to pass.

\section{WATER QUALITY INDEX (WQI)}

Table 9 shows the summary of the calculated WQI values for the mine water samples before and after the membrane treatment using (2). The raw Sample 1 collected from Bandar Saujana Putra Jenjarom was found to have a calculated MQI value of 51.95 and is hence categorized as polluted water. However, the sample might be suitable for water supply if subjected to further treatment. After the membrane filtration, the WQI value increased to 52.68 for the UF membrane (10 kDa) and to 54.38 for the RO membrane module, but slightly decreased to 47.64 for the UF membrane $(5 \mathrm{kDa})$. Although the membrane technology was able to partly treat the Sample 1 mine water, the quality of the treated permeate water was still suboptimal and did not meet the standard for public use as it was highly polluted.

The raw Sample 2 collected from Taman Putra Perdana, Puchong was found to have a calculated MQI value of 58.95. Similar to Sample 1, Sample 2 is hence categorized as polluted water with a slightly better quality that could be used for recreational purposes. After the membrane filtration, the WQI value increased to 59.81 for the UF membrane ( $5 \mathrm{kDa}$ ) and to 59.09 for the RO membrane, but slightly decreased to 51.67 for the UF membrane $(10 \mathrm{kDa})$. Further treatment is suggested as the quality of the resultant permeates water did not meet the standard for residential use.

The raw Sample 3 collected from Persiaran Puchong Perdana, Puchong was found to have a calculated MQI value of 62.85 . This sample exhibited the best water quality among the raw mine water samples. After the membrane filtration, the WQI value increased to 63.91 for the UF membrane $(5 \mathrm{kDa})$ and 65.04 for the RO membrane, but slightly decreased to 60.96 for the UF membrane (10 kDa). Although the treated mine water samples did not attain the standard for residential use and were thus not suitable for direct usage, they were still safe to be used for household purposes after appropriate treatment, such as integrated membrane filtration.

\section{WATER TREATMENT PLANT DESIGN USING MEMBRANE TECHNOLOGY}

Besides ensuring the safety of the mine water, it is important to determine the capacity of the available mine water and the capability of its continuous supply to the citizens of Selangor. According to the report by Suruhanjaya Perkhidmatan Air Negara in 2013, the volume of water used by the citizens was 235 liter per head per day. As the total population of Selangor in 2014 was $5,870,000$ (Department of Statistics Malaysia 2014), the total volume of water used by its citizens is estimated to be 1,379,450,000 liter per day, which is equal to $1,379,450$ $\mathrm{m}^{3}$ of water per day. In order to calculate the duration of its continuous supply to the citizens in Selangor, Equation (3) was applied.

$$
\begin{aligned}
\text { Mine water supply }(\text { Days })= & \text { Volume of mine }\left(\mathrm{m}^{3}\right) \\
& \div 1,379,450 \mathrm{~m}^{3} / \text { day }
\end{aligned}
$$

Accordingly, for each of the mine areas from which the samples were collected, both the total volume of mine water and the duration of continuous supply were estimated. For Bandar Saujana Putra, Jenjarom (collection of Sample 1), the mine area is $779431 \mathrm{~m}^{2}$ while the depth is assumed to be $156 \mathrm{~m}$ (Hassan \& Purwanto 2003). Thus, the total volume of mine water that can be supplied is $121,591,236 \mathrm{~m}^{3}$, which could support up to 88 days of usage by the citizens of Selangor. For Taman Putra Perdana, Puchong (collection of Sample 2), the mine area is $1,880,000 \mathrm{~m}^{2}$ with the depth is assumed to be $156 \mathrm{~m}$. Thus, the total volume is $293,280000 \mathrm{~m}^{3}$, which could support up to 212 days of usage. For Persiaran Puchong Perdana, Puchong (collection of Sample 3), the mine area is approximately $1,030,000 \mathrm{~m}^{2}$ and the depth is assumed to be $156 \mathrm{~m}$ (Hassan \& Purwanto 2003). Thus, the total volume is $160,680,000 \mathrm{~m}^{3}$, which could support up to 212 days of usage. Based on the calculated mine water capacities, these mine areas are suitable as the supply to channel water to dams for usage by the citizens of Selangor as they could afford continuous water supply for long periods during water crises.

A three-stage integrated membrane filtration system as depicted in Figure 3 was proposed in this study in order to improve the efficiency of the mine water treatment plant and to produce the permeate water that will eventually have a high quality suitable for residential use. The membrane filtration starts with the UF membrane module with MWCO of $10 \mathrm{kDa}$ with a larger membrane pore size to pre-filter the raw water sample, followed by the UF membrane module with MWCO of $5 \mathrm{kDa}$ and lastly the RO membrane module. Several alternative pathways have been designed in this system for feed water of different qualities for different seasons or locations. For a

TABLE 9. Water Quality Index (MQI) of mine water before and after membrane treatment

\begin{tabular}{cccc}
\hline & Sample 1 & Sample 2 & Sample 3 \\
\hline Raw & 51.95 & 58.95 & 62.85 \\
UF (10 kDa) & 52.68 & 51.67 & 60.96 \\
UF (5 kDa) & 47.64 & 59.81 & 63.91 \\
RO & 54.38 & 59.09 & 65.04 \\
\hline
\end{tabular}




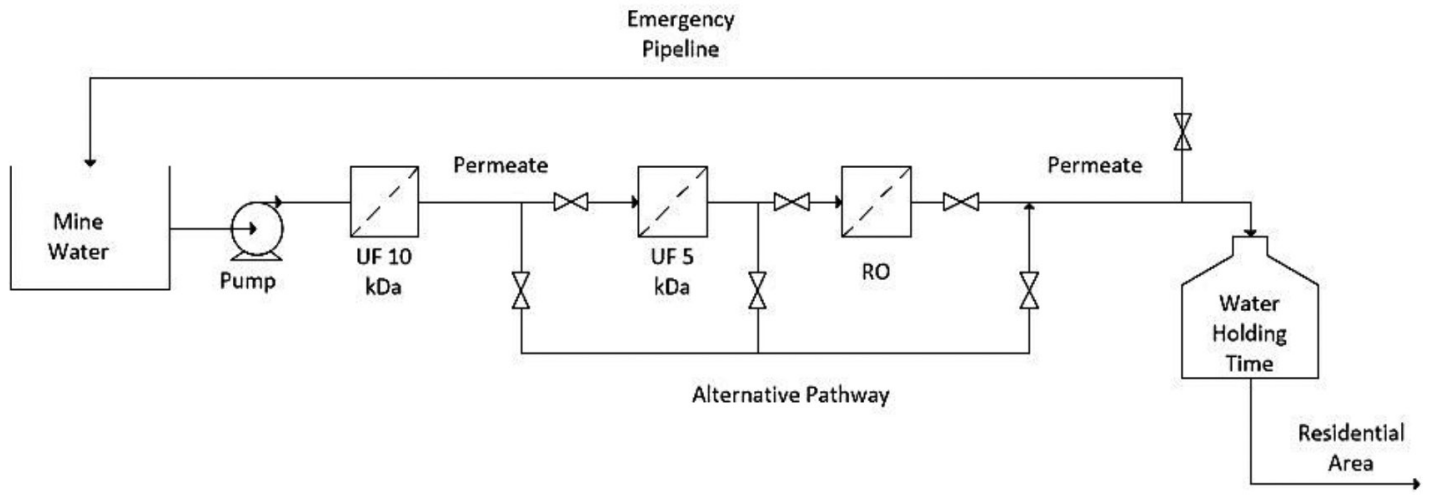

FIGURE 3. Suggestion for mine water treatment plant

better quality of the feed water, fewer stages of membrane filtration stage are needed to improve the water quality. In such circumstances, the alternative pathway can be applicable. The resulting permeate water from the system will be kept in a water-holding tank before being supplied to residential areas.

\section{CONCLUSION}

In conclusion, this study has highlighted the potential utility of membrane technology in the treatment of mine water in enhancing the water quality with respect to aspects such as COD, BOD, DO, TSS, color, turbidity, conductivity, TDS, $\mathrm{NH}_{3}-\mathrm{N}$ and heavy metals. Different membrane modules have demonstrated different extents of removal efficiency, depending on the rejection capability of the membranes, which in turn is predominantly governed by the membrane morphology. Given its tight membrane structure, the RO membrane module has the best performance in producing permeate water of an excellent quality. However, this contrasts with the lower permeate flux due to the smaller pore size of the membrane module. Unfortunately, none of the water produced from these single-membrane systems was able to meet the standard for residential use. Therefore, an integrated membrane filtration system with three stages of membrane filtration (UF membrane module with MWCO of $10 \mathrm{kDa}$, UF membrane module with MWCO of $5 \mathrm{kDa}$ and RO membrane module) is designed and proposed for future studies to further improve the water quality, eventually leading to the attainment of the water standard for residential use.

\section{ACKNOWLEDGEMENTS}

This work was supported by Geran Universiti Penyelidikan (GUP-2017-098) and Indah Water Konsortium Sdn. Bhd. (KK-2018-005).

\section{REFERENCES}

Baird, R.B., Eaton,A.D. \& Clesceri, L.S. 2012. Standard Methods for the Examination of Water and Wastewater. Location: American Water Works Association.
Bernal, M.P. \& McGrath, S.P. 1994. Effects of pH and heavy metal concentrations in solution culture on the proton release, growth, and element composition of Alyssum murale and Raphanus sativus L. Plant and Soil 166: 83-92.

Brake Perry, F. 1998. Supplemental Guidance for the Determination of Biochemical Oxygen Demand (BODs) and Carbonaceous BOD (CBODs) in Water and Wastewater. Washington State Department of Ecology Environmental Assessment Program. Lab Accreditation Section. Publication No. 98-307.

Department of Environment Malaysia (DOE). 2008. Interim National Water Quality Standard for Malaysia. http://www. doe.gov.my/index.php?option=comContent\&task=view\&id $=244 \&$ Itemid=615\&lang=en. Accessed on August 19, 2015 .

Department of Statistics Malaysia. 2014. Statistic at Selangor. https://www.statistics.gov.my. Accessed on June 8, 2015.

Field, R. 2010. Fundamentals of fouling, in membrane technology. In Membranes for Water Treatment, Volume 4, edited by Peinemann, K.V. \& Nunes, S.P. Weinheim: WileyVCH Verlag GmbH \& Co. KgaA.

GEA Filtration. 2010. Membrane Filtration Process. http://www. geafiltration.com/technology/technology.asp. Accessed on August 16, 2015.

Georgescu, D.P. \& Anderi, L. 2000. Treatment of tailings water from uranium ore processing by reverse osmosis. Uranium 2000: International Symposium on the Process Metallurgy of Uranium 35(43): 9-15.

Hassan, W.F.W. \& Purwanto, H.S. 2003. Analisis bendalir terkepung pada Telerang Kuarza, Kuala Lipis dan Lubok Mandi, Terengganu, Semenanjung Malaysia. Bulletin of the Geological Society of Malaysia 46: 359-363.

Hydranautics. 2001. Design Parameters Affecting Performance. https://www.google.com/url?sa=t\&rct=j\&q=\&esrc=s\&sourc e=web $\&$ cd $=2 \& v e d=0 C C w Q F j A B a h U K E w j g v f u A i a 3 H A h V$ FC44KHarkARY\&url=http\%3A\%2F\%2Fwww.membranes. com $\% 2$ Fdocs $\% 2 \mathrm{Ftrc} \% 2 \mathrm{Fdesparam}$. pdf\&ei=dzrQVaCmEsW WuASqyYewAQ\&usg=AFQjCNHVoRdQBmMH3i5e2fG9 JoioIQuWew\&bvm=bv.99804247,d.c2E\&cad=rja. Accessed on August 16, 2015.

Jabatan Alam Sekitar. 2010. Malaysia Environment Quality Report.

Kesieme, U.K. \& Aral, H. 2015. Application of membrane distillation and solvent extraction for water and acid recovery from acidic mining waste and process solutions. Journal of Environmental Chemical Engineering 3(3): 2050-2056. 
Mullett, M., Fornarelli, R. \& Ralph, D. 2014. Nanofiltration of mine water: Impact of feed $\mathrm{pH}$ and membrane charge on resource recovery and water discharge. Membranes 4(2): 163-180.

Nanda, D., Tung, K.L., Li, Y.L., Lin, N.J. \& Chuang, C.J. 2010. Effect of $\mathrm{pH}$ on membrane morphology, fouling potential, and filtration performance of nanofiltration membrane for water softening. Journal of Membrane Science 349: 411-420.

Rozkowski, A. \& Rozkowski, J. 1994. Impact of mine waters on river water quality in the upper Silesian Coal Basin. $5^{\text {th }}$ International Mine Water Congress, Nottingham (U.K.). pp. 811- 821 .

Sivakumar, M., Morton, S.G.S. \& Singh, R.N. 1994. Case history analysis of mine water pollution in New South Wales, Australia. $5^{\text {th }}$ International Mine Water Congress, Nottingham (U.K.). pp. 823- 834.

Suruhanjaya Perkhidmatan Air Negara. 2013. Jumlah Penggunaan Air (2009-2010). http://www.span.gov.my.html. Accessed on 5 May 2015.

Wilmoth, R.C., Baugh, T.L. \& Decker, D.W. 1978. Removal of selected trace elements from acid mine drainage using existing technology. $33^{\text {rd }}$ Industrial Waste Conference. pp. 886-894.
Teow Yeit Haan*, Abdul Wahab Mohammad \& Mohd Shaiful Sajab

Research Centre for Sustainable Process Technology (CESPRO)

Faculty of Engineering and Built Environment

Universiti Kebangsaan Malaysia

43600 UKM Bangi, Selangor Darul Ehsan

Malaysia

Teow Yeit Haan*, Abdul Wahab Mohammad, Syazaman Ramli, Mohd Shaiful Sajab \& Noorini Izzati Mohamad Mazuki

Chemical Engineering Programme

Faculty of Engineering and Built Environment

Universiti Kebangsaan Malaysia

43600 UKM Bangi, Selangor Darul Ehsan

Malaysia

*Corresponding author; email: yh_teow@ukm.edu.my

Received: 22 May 2018

Accepted: 22 July 2018 